\title{
INVESTIGATION ON STRENGTH OF CONCRETE WITH MINERAL ADMIXTURES
}

\author{
S. VENKATRAMM ${ }^{1}$, G. VIMALANANDAN ${ }^{2}$ \& S. SENTHILSELVAN ${ }^{3}$ \\ ${ }^{I}$ M.Tech graduate, Structural Engineering, SRMIST, Tamil Nadu, India \\ ${ }^{2}$ Assistant Professor, Department of Civil Engineering, SRMIST, Tamil Nadu, India \\ ${ }^{3}$ Professor, Department of Civil Engineering, SRMIST, Tamil Nadu, India
}

\begin{abstract}
Concrete is a most broadly and commonly utilized construction material right now and about six billion tonnes was
produced each year and was next to the water production. However for the production of cement which is considered as a
primary substance for the concrete production and this heavy production of cement can damage the atmosphere by
releasing Carbon-di oxide. Therefore, the concept of green concrete is introduced to lessen the damage caused by the
production of cement. In this work, investigation is made on properties of concrete when it is partially replaced with
Ground granulated blast slag (GGBS) and Silica fume instead of cement. On account of its physical and chemical
properties, it is more reactive pozzolanic substitute. Silica fume when added to concrete provides high strength and can be
highly durable. The replacement levels of $30 \%, 50 \%$ and $70 \%$ of cement with GGBS and $5 \%$ of Silica fume is added onto
the $50 \%$ of GGBS on concrete cubes of $150 x 150 x 150$ mm size on M20 and M40 grades of concrete. The replacement level
$30 \%$ of cement with GGBS is considered to be the optimum replacement level. The curing periods for these cubes and
cylinders were 7 days, 28 days and 56 days.
KEYWORDS: Concrete, Production, Compressive Strength, Split Tensile Strength, Replacement, Percentage
\end{abstract}
Received: Jun 06, 2020; Accepted: Jun 26, 2020; Published: Aug 31, 2020; Paper Id.: IJMPERDJUN2020970

\section{INTRODUCTION}

Cement is basic constituent for the preparation of the concrete and nearly 6 billion tonnes is produced per year and due to this heavy production of cement there maybe damage to the atmosphere due to the release of $\mathrm{CO}_{2}$ to the atmosphere. Due to this release, green concrete is adopted worldwide and is effective because of the use of wastage residues from the various manufacturing industries which have similar properties similar to cement. These wastage residues can be used in concrete in the place of cement either wholly or partially. The presence of $12 \%$ of Portland cement accounts for $93 \%$ of strength of the cement concrete. This combination of the waste products by replacing the cement is together called as a self-compacting concrete and its important factor is developed by increasing the performance of concrete and the working environment. SCC is highly effective in terms of binding and durability properties.

GGBS is a residual material obtained in the processing of iron ore. The GGBS composition exactly similar to the cement composition and so it is used. The use of GGBS can also have resistance to the permeability of water into the concrete structures and also have high resistance towards the corrosion of the reinforcement from various harmful gases like sulphates and chlorides. Due to the micro-structural properties the use of GGBS can also used as a microfiller in the concrete structures. This use of GGBS can cause reduction in the dumping of waste. Effective usage of GGBS reduces atmospheric pollution. It also subsequently enhances service lifetime and reduce maintenance cost

Silica fume is an amorphous polymorph of silicon di-oxide. During the silicon and ferrosilicon alloy 
manufacture, a residual material which is an ultra-fine powder is collected and is called as silica fume. During the last three decades, mainly Silica fume (SF) and fly ash individually or in combination are incomparable in production of high strength concrete for practical application in construction. The use of silica fume can enhance the various properties such as cohesiveness, strength, permeability and durability. Silica fume concrete may be highly used in places where high abrasion resistance and low permeability are of utmost importance or where very high cohesive mixes are required to avoid segregation and bleeding.

\section{REVIEW OF LITERATURE}

Bahador Sabet Divsholi et al have experimented that by the usage of GGBS the micro-pore structure in the concrete was reduced. In the compression testing, it was found that the replacement level of $30 \%$ of GGBS found to be good and the value of slump was increased by 20\%,35\% and 55\%. Mohan kumar et al have made a research that by using GGBS at varied percentages and found that the about $20 \%$ GGBS have better compression and tensile strength after certain days of curing. It has better resistance power against Concentrated Hydrochloric acid $(\mathrm{HCl})$ and Sodium hydroxide $(\mathrm{NaOH})$ for replacement level of GGBS of about 50\% in M40 grade concrete. J. Vengadesh et al have made a study on mechanical properties GGBS for the percentage replacement levels of about $25 \%, 30 \%, 35 \%$ and $40 \%$. In this study he found that the GGBS of about $25 \%$ replacement has maximum compressive strength, it improves the flexural strength also. However, there is reduction in strength beyond 30\% replacement level. Santosh Kumar Karri et al had done a work on obtaining maximum strength by using GGBS for the replacement levels of about $0 \%, 30 \%, 40 \%$ and $50 \%$ for various tests for 28 and 90 days of curing under water for two different mixes of concrete and the highest strength is achieved in $40 \%$ of replacement. A. Jayseeliabitha et al found a research on the replacement levels of about $0 \%, 10 \%, 20 \%$ and $30 \%$ of GGBS and micro silica each and have found that for $30 \%$ of replacement the strength is enhanced abruptly in mechanical characteristic tests compared to conventional concrete. Shreyas. $\mathbf{K}$ have made an experiment by altering the use of admixture GGBS in the place of cement for the replacement level of $30 \%$ and have obtained maximum strength in mechanical testing mechanisms. Also, replacement above $40 \%$ can increase the durability and workability characteristics of the concrete.

\section{EXPERIMENTAL WORK}

\section{Methodology}

- The basic materials for casting such as manufactured sand, cement and coarse aggregate with admixtures like GGBS and silica fume were collected

- The preliminary tests were done on these basic materials and those values were noted down

- With those initial test values, design mix was calculated for M20 and M40 grade concrete by using IS 10262:2009

- According to the mix design, the cubes and cylinders were casted for these grade concrete mixes along with the varied percentages of GGBS and silica fume

- These cubes and cylinders were then tested under compression testing machine

- Optimum replacement level for M20 grade mix and forM40 grade mix of concrete with replacement percentages were found 


\section{PROPERTIES OF MATERIALS}

\section{Cement}

Construction industry is highly dependent on the basic material called cement. When present in concrete produces increase in microstructural properties for its better performance. In this project work, 53 grade of cement is used.

Table 1: Properties of Cement

\begin{tabular}{|l|c|}
\hline Specific Gravity & 3.14 \\
\hline Fineness & $3 \%$ \\
\hline Consistency & $30 \%$ \\
\hline Initial Setting Time & 40 minutes \\
\hline
\end{tabular}

\section{Fine Aggregate}

In my present work, manufactured sand was replaced by river sand. It is one of the important constituents of concrete. It possess high strength, durability and shape characteristics.

Table 2: Properties of M. Sand

\begin{tabular}{|l|c|}
\hline Specific Gravity & 2.81 \\
\hline Grade Zone & ZONE II \\
\hline
\end{tabular}

\section{Coarse Aggregate}

It is the basic material used in the concrete mix. They are also used in the preparation of the moisture break under the slab and vapour barrier. Here, we use aggregate passing below $20 \mathrm{~mm}$ of size sieve.

Table 3: Properties of Coarse Aggregate

\begin{tabular}{|l|c|}
\hline Specific Gravity & 2.85 \\
\hline
\end{tabular}

\section{GGBS}

Ground granulated blast slag is a resulting product from heating of molten iron slag at several temperatures in a water or stream from blast furnace. This is then kept for drying and was powdered to form a glassy and granular product called GGBS

Table 4: Properties of GGBS

\begin{tabular}{|l|l|}
\hline Specific Gravity & 2.54 \\
\hline
\end{tabular}

\section{Silica Fume}

Silica fume is a resulting material obtained by manufacturing of a silicon metal. This is one of the important addition to the concrete to improve its quality.

Table 5: Properties of Silica Fume

\begin{tabular}{|l|l|}
\hline Specific Gravity & 2.24 \\
\hline
\end{tabular}




\section{EXPERIMENTAL INVESTIGATION}

\section{General}

The concrete cubes of size $150 \mathrm{mmx} 150 \mathrm{~mm}$ and concrete cylinders of size $100 \mathrm{~mm}$ (diameter) and $200 \mathrm{~mm}(\mathrm{height}) \mathrm{were}$ both casted for M20 and M40 mix of concrete as per IS 10262-2009. The different replacement percentages of GGBS and silica fume is done along with the conventional mix design calculation and the mix proportions were formulated.

\section{Mix Design}

M20 and M40 grademix along with admixtures of GGBS and Silica fume are obtained at various replacement percentages.

\section{Mix Design for M20 Grade Concrete}

The M20 grade mix design calculation is done and the quantity of materials is calculated and tabulated in table 7 .

Table 6: Stipulations for Proportioning of M20 Concrete Mix

\begin{tabular}{|c|l|c|}
\hline S. NO & \multicolumn{1}{|c|}{ DESCRIPTION } & VALUES \\
\hline 1 & Grade of concrete & M20 \\
\hline 2 & Type of cement & OPC 53 grade \\
\hline 3 & Maximum size of aggregate & $20 \mathrm{~mm}$ \\
\hline 4 & Aggregate type & Crushed angular aggregate \\
\hline 5 & Exposure condition & Moderate \\
\hline 6 & Maximum water cement ratio & 0.5 \\
\hline 7 & Minimum cement content & $300 \mathrm{~kg} / \mathrm{m}^{3}$ \\
\hline 8 & Maximum cement content & $383.16 \mathrm{~kg} / \mathrm{m}^{3}$ \\
\hline 9 & Workability & $75 \mathrm{~mm} \mathrm{slump}$ \\
\hline
\end{tabular}

Table 7: Quantity of Materials for M20 Grade Concrete

\begin{tabular}{|l|c|c|c|c|}
\hline \multirow{2}{*}{ MATERIALS Kg/m } & \multicolumn{4}{|c|}{ GGBS CONTENT } \\
\cline { 2 - 5 } & $\mathbf{0 \%}$ & $\mathbf{3 0 \%}$ & $\mathbf{5 0 \%}$ & $\mathbf{7 0 \%}$ \\
\hline Cement & 383.16 & 268.21 & 191.58 & 114.95 \\
\hline Coarse aggregate & 1194.49 & 1180.36 & 1169.75 & 1157.39 \\
\hline Fine aggregate & 721.83 & 713.29 & 706.88 & 699.41 \\
\hline GGBS & 0 & 114.95 & 191.58 & 268.2 \\
\hline Water & 192 & 192 & 192 & 192 \\
\hline Silica fume & 0 & 0 & 19.16 & 0 \\
\hline
\end{tabular}

Comparing the values of table 7 the mix ratio for M20 grade of concrete is found to be

$\begin{array}{ccccc}\text { Cement }: & \text { Fine aggregate }: & \text { Coarse aggregate }: & \text { Water } \\ 1 & 1.88 & 3.1 & 0.5\end{array}$

\section{Mix Design for M40 Grade Concrete}

The M40 grade mix design calculation is done and the quantity of materials is calculated and tabulated in table 9. 
Table 8: Stipulations for Proportioning of M40 Concrete Mix

\begin{tabular}{|c|l|c|}
\hline S. NO & \multicolumn{1}{|c|}{ DESCRIPTION } & VALUES \\
\hline 1 & Grade of concrete & M40 \\
\hline 2 & Type of cement & OPC 53 grade \\
\hline 3 & Maximum size of aggregate & $20 \mathrm{~mm}$ \\
\hline 4 & Aggregate type & Crushed angular aggregate \\
\hline 5 & Exposure condition & Moderate \\
\hline 6 & Maximum water cement ratio & 0.4 \\
\hline 7 & Minimum cement content & $300 \mathrm{~kg} / \mathrm{m}^{3}$ \\
\hline 8 & Maximum cement content & $478.95 \mathrm{~kg} / \mathrm{m}^{3}$ \\
\hline 9 & Workability & $75 \mathrm{~mm} \mathrm{slump}$ \\
\hline
\end{tabular}

Table 9: Quantity of Materials for M40 Grade Concrete

\begin{tabular}{|l|c|c|c|c|}
\hline \multirow{2}{*}{ MATERIALS Kg/m } & \multicolumn{4}{|c|}{ GGBS CONTENT } \\
\cline { 2 - 5 } & $\mathbf{0 \%}$ & $\mathbf{3 0 \%}$ & $\mathbf{5 0 \%}$ & $\mathbf{7 0 \%}$ \\
\hline Cement & 478.95 & 335.10 & 239.48 & 143.69 \\
\hline Coarse aggregate & 1178.30 & 1156.42 & 1149.38 & 1129.38 \\
\hline Fine aggregate & 653.49 & 641.35 & 634.68 & 626.38 \\
\hline GGBS & 0 & 143.69 & 239.48 & 335.27 \\
\hline Water & 192 & 192 & 192 & 192 \\
\hline Silica fume & 0 & 0 & 23.95 & 0 \\
\hline
\end{tabular}

Comparing the values of table 9 the mix ratio for M40 grade of concrete is found to be

$$
\begin{array}{ccccc}
\text { Cement : } & \text { Fine aggregate }: & \text { Coarse aggregate }: & \text { Water } \\
1 & 1.36 & 2.46 & 0.4
\end{array}
$$

\section{TEST AND RESULTS}

\section{Compression Test Results}

The test for compression is done for the replacement percentages of $0 \%, 30 \%, 50 \%$ and $70 \%$ with GGBS and its values were obtained at varied intervals of curing and for replacement percentages of $50 \%$ of GGBS with $5 \%$ of silica fume and the results were obtained after 28 days and 56 days of curing.

Table 10: Compressive Strength for M20 Grade Concrete

\begin{tabular}{|c|c|c|c|c|}
\hline \multirow{2}{*}{$\begin{array}{c}\text { Grade of } \\
\text { Concrete }\end{array}$} & $\begin{array}{c}\text { \% Replacement } \\
\text { of Cement with }\end{array}$ & \multicolumn{2}{|c|}{ Compression Strength for Specimens (N/mm $\left.\mathbf{m}^{\mathbf{2}}\right)$} \\
\cline { 3 - 5 } & GGBS & $\mathbf{7}$ days & $\mathbf{2 8}$ days & 56 days \\
\hline \multirow{3}{*}{ M20 } & $0 \%$ & 25.51 & 27.73 & 37.32 \\
\cline { 2 - 5 } & $30 \%$ & 18.59 & 33.53 & 37.96 \\
\cline { 2 - 5 } & $50 \%$ & 25.94 & 32.29 & 22.57 \\
\cline { 2 - 5 } & $70 \%$ & 12.14 & 21.24 & \multicolumn{2}{c}{} \\
\hline
\end{tabular}

Table 11: Compressive Strength for M40 Grade Concrete

\begin{tabular}{|c|c|c|c|c|}
\hline \multirow{2}{*}{$\begin{array}{c}\text { Grade of } \\
\text { Concrete }\end{array}$} & $\begin{array}{c}\text { \% Replacement } \\
\text { of Cement with } \\
\text { GGBS }\end{array}$ & \multicolumn{3}{|c|}{ Compression Strength for Specimens (N/mm $\left.\mathbf{m}^{\mathbf{}}\right)$} \\
\cline { 2 - 5 } & $0 \%$ & $\mathbf{7}$ days & $\mathbf{2 8}$ days & $\mathbf{5 6}$ days \\
\hline \multirow{3}{*}{ M40 } & $30 \%$ & 29.95 & 39.77 & 41.01 \\
\cline { 2 - 5 } & $50 \%$ & 32.42 & 36.35 & 42.97 \\
\cline { 2 - 5 } & $70 \%$ & 18.70 & 29.88 & 33.18 \\
\cline { 2 - 5 } & \multicolumn{3}{|c}{} \\
\hline
\end{tabular}




\section{COMPRESSIVE STRENGTH FOR M20 GRADE CONCRETE}

$\left(\mathrm{N} / \mathrm{mm}^{2}\right)$

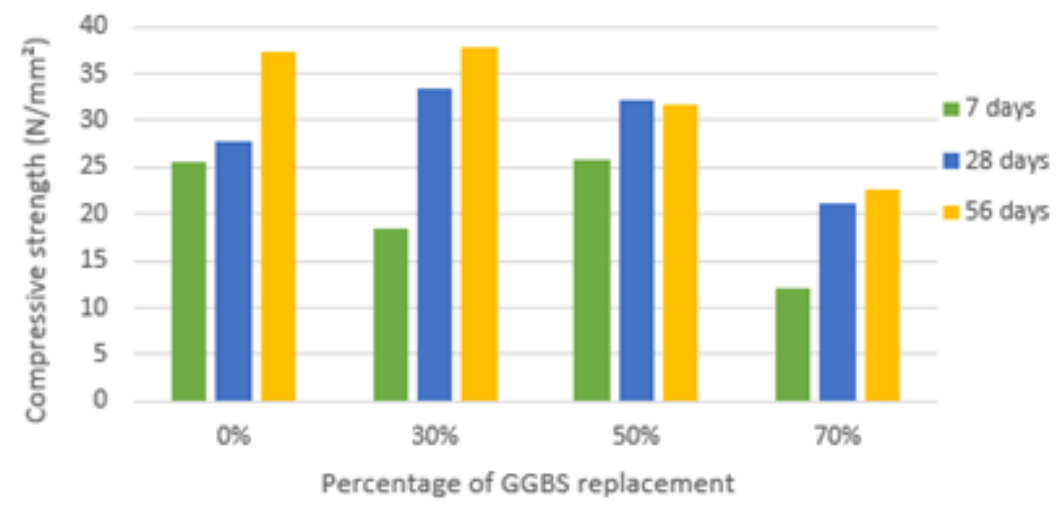

Figure 1

COMPRESSIVE STRENGTH FOR M40 GRADE CONCRETE

$\left(\mathrm{N} / \mathrm{mm}^{2}\right)$

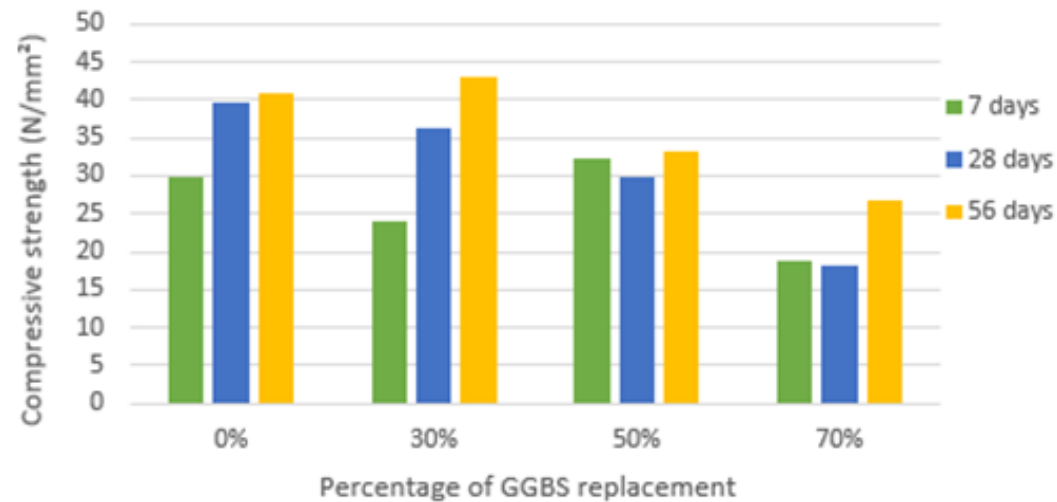

Figure 2

Table 12: Compressive Strength for M20 Grade Concrete with 5\% of Silica Fume

\begin{tabular}{|c|c|c|c|}
\hline \multirow{2}{*}{$\begin{array}{c}\text { Grade of } \\
\text { Concrete }\end{array}$} & $\begin{array}{c}\text { \% Replacement of } \\
\text { Cement with GGBS }+\end{array}$ & \multicolumn{2}{|c|}{$\begin{array}{c}\text { Compression Strength } \\
\text { for Specimens (N/mm }\end{array}$} \\
\cline { 3 - 4 } & $\mathbf{5 \%}$ of Silica Fume & $\mathbf{2 8}$ days & $\mathbf{5 6}$ days \\
\hline \multirow{2}{*}{ M20 } & $0 \%$ & 27.73 & 37.32 \\
\cline { 2 - 4 } & $50 \%$ & 26.02 & 30.47 \\
\hline
\end{tabular}

COMPRESSIVE STRENGTH FOR M20 GRADE CONCRETE $\left(\mathrm{N} / \mathrm{mm}^{2}\right)$

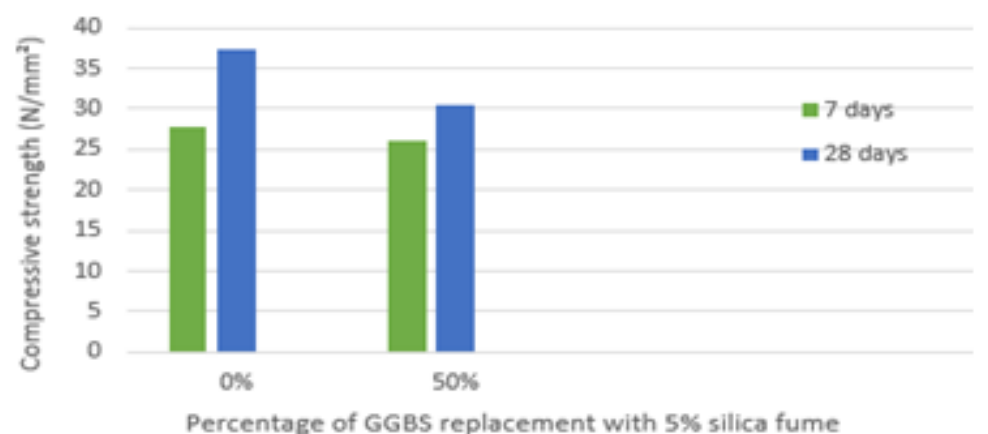

Figure 3 
Table 13: Compressive Strength for M40 Grade Concrete with $5 \%$ of Silica Fume

\begin{tabular}{|c|c|c|c|}
\hline \multirow{2}{*}{$\begin{array}{c}\text { Grade of } \\
\text { Concrete }\end{array}$} & \multirow{2}{*}{$\begin{array}{c}\text { \% Replacement of } \\
\text { Cement with GGBS } \\
\end{array}$} & \multicolumn{2}{|c|}{$\begin{array}{c}\text { Compression Strength } \\
\text { for Specimens }\left(\mathbf{N} / \mathbf{m m}^{\mathbf{2}} \text { ) }\right.\end{array}$} \\
\cline { 3 - 4 } & $0 \%$ & $\mathbf{2 8}$ days & $\mathbf{5 6}$ days \\
\hline \multirow{2}{*}{ M40 } & $50 \%$ & 39.77 & 41.01 \\
\cline { 2 - 4 } & & 36.68 & 37.50 \\
\hline
\end{tabular}

\section{COMPRESSIVE STRENGTH FOR M40 GRADE CONCRETE}

$\left(\mathrm{N} / \mathrm{mm}^{2}\right)$

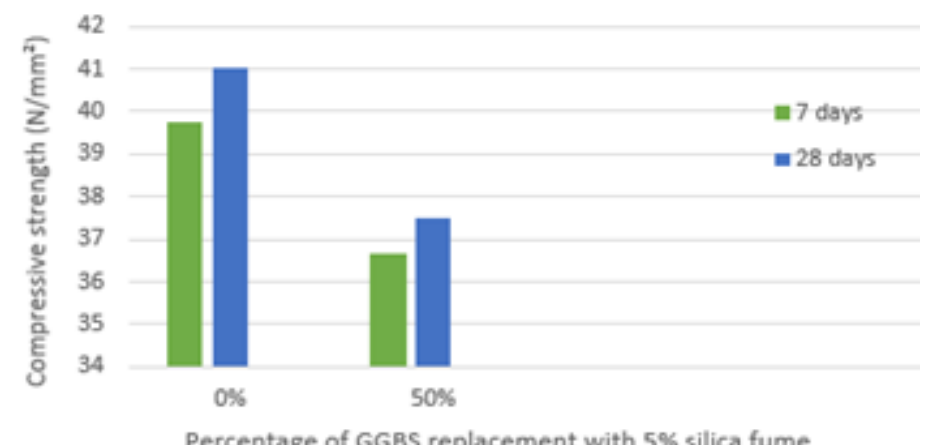

Figure 4

\section{Split Tensile Test Results}

The test for tensile is done for the replacement percentages of $0 \%$ and $50 \%$ with GGBS and the resulting values were obtained at three intervals of curing.

Table 14: Split Tensile Strength for M20 Grade Concrete

\begin{tabular}{|c|c|c|c|c|}
\hline \multirow{2}{*}{$\begin{array}{c}\text { Grade of } \\
\text { concrete }\end{array}$} & \multirow{2}{*}{$\begin{array}{c}\text { \% replacement } \\
\text { of cement with } \\
\text { GGBS }\end{array}$} & \multicolumn{3}{|c|}{$\begin{array}{c}\text { Split tensile strength for } \\
\text { specimens }\left(\mathbf{N} / \mathbf{m m}^{2}\right)\end{array}$} \\
\cline { 3 - 5 } & $\mathbf{7}$ days & $\mathbf{2 8}$ days & $\mathbf{5 6}$ days \\
\hline \multirow{2}{*}{ M20 } & $0 \%$ & 2.067 & 3.08 & 2.41 \\
\cline { 2 - 5 } & $50 \%$ & 1.55 & 2.88 & 2.57 \\
\hline
\end{tabular}

\section{SPLIT TENSILE STRENGTH FOR M20 GRADE CONCRETE} $\left(\mathrm{N} / \mathrm{mm}^{2}\right)$

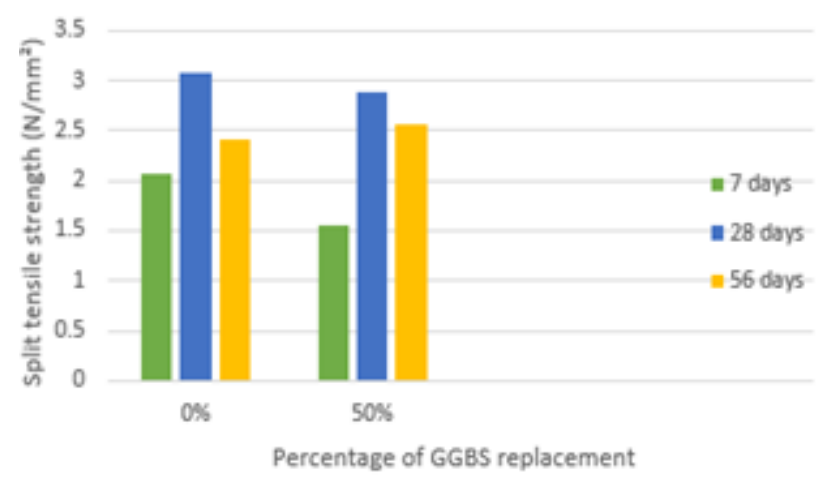

Figure 5 
Table 15: Split Tensile Strength for M40 Grade Concrete

\begin{tabular}{|c|c|c|c|c|}
\hline \multirow{2}{*}{$\begin{array}{c}\text { Grade of } \\
\text { Concrete }\end{array}$} & \multirow{2}{*}{$\begin{array}{c}\text { Replacement of } \\
\text { Cement with } \\
\text { GGBS }\end{array}$} & \multicolumn{3}{|c|}{$\begin{array}{c}\text { Split Tensile Strength for } \\
\text { Specimens (N/mm }\end{array}$} \\
\cline { 3 - 5 } & & $\mathbf{7}$ days & $\mathbf{2 8}$ days & $\mathbf{5 6}$ days \\
\hline \multirow{2}{*}{ M40 } & $0 \%$ & 2.85 & 2.36 & 3.44 \\
\cline { 2 - 5 } & $50 \%$ & 1.45 & 2.67 & 3.74 \\
\hline
\end{tabular}

SPLIT TENSILE STRENGTH FOR M40 GRADE CONCRETE $\left(\mathrm{N} / \mathrm{mm}^{2}\right)$

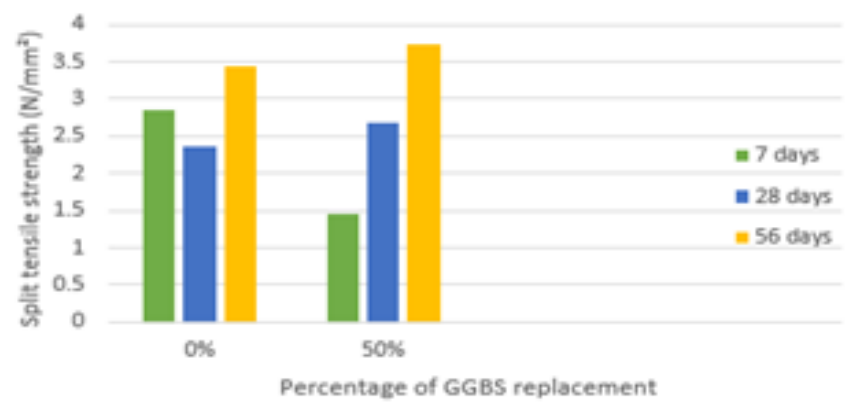

Figure 6

\section{CONCLUSIONS}

- The compressive strength for M20 grade and M40 grade concrete mixes with 50\% of cement quantity replacement with GGBS after 7 days of curing showed $1.69 \%$ and $8.24 \%$ increase respectively.

- The strength for compression for M20 grade concrete with 30\% in partial replacement of cement with GGBS after 28 days of curing showed $21 \%$ increase.

- The compressive strength for M40 grade of concrete with 30\% of partial replacement quantity of cement with GGBS after 56 days of curing showed $5 \%$ increase.

- The compressive strength of M20 and M40 grade concretes with 50\% replacement of cement with GGBS showed increase value after 7 days of curing.

- The compressive strength of M20 grade concrete with 30\% replacement of cement with GGBS showed increase value after 28 days of curing

- The compressive strength of M20 grade concrete with 30\% replacement of cement with GGBS showed increase value after 56 days of curing

- The split tensile strength for M40 grade of concrete with 50\% partial replacement of cement with GGBS after 56 days of curing shows the better result.

\section{REFERENCES}

1. Bahador Sabet Divsholi et al(2013), "Durability Properties and Microstructure of Ground Granulated Blast Furnace Slag Cement Concrete",.

2. Shreyas (2017) "Characteristics of GGBS as an Alternate Material in Conventional Concrete”, Volume 5, Issue 4 December.

3. B.Kaviya (2017), "Study of partial replacement of cement by ground granulated blast furnance slag", Volume 116,No.13. 
4. Mohan kumar et al (2017) "Strength and durability studies on concrete with partial replacement of cement with GGBS", Volume 3(8)

5. Santhoshkumar karri et al (2015) "Strength and durability studies of concrete”, Volume 2 ,Issue 10.

6. A.Jayseeliabitha et al (2017) has done their work on "Experimental investigation of high strength in which cement is partially replaced with GGBS and Silica fume”, Volume 8,Issue 10.

7. V.Gopi et al (2019), "Experimental Investigation on Strength and Durability of Concrete Incorporated with Silica Fume and Fly Ash", Volume 7

8. Manjunatha andJeevan (2015), "Study of Early Age Properties and behavior of concrete with GGBS as partial replacement of cement", Volume 4.

9. Lakhbirsingh et al (2016) has done their work on "Study on Partial Replacement of cement by Silica Fume", Volume 4,Issue 7.

10. SonaliK.Gadplliwar et al (2014) "Partial replacement of cement with the help of GGBS and RHA and replacement of Quarry sand with that of Natural sand", Volume 11, Issue 2 Ver. II.

11. Subathra Devi V et al (2018) "Investigation on the Strength and Durability of concrete with GGBS and Silica fume", Volume 8,Issue

12. Musalaiah, G., Shireesha, Y., Kumar, P. K., \& Raju, P. S. (2017). Compressive and Flexural Strength Improvement of Jute Fibre Reinforced Polymer Composite. International Journal of Mechanical and Production Engineering Research and Development (IJMPERD), 7(4), 235-240.

13. Purushothaman, M., \& Senthamarai, R. M. (2013). Strength properties of high performance concrete using bottom ash as fine aggregate. International Journal of Civil, 2(3), 35-40.

14. Jery, C., Raj, J., Vs, L., \& Chacko, A. Effect of Coconut Shell Powder on the Strength of Soil.

15. Rajesh, S., Ramnath, B. V., Prashanth, B., \& Kumar, M. P. An Effect of Fiber Orientation of Tensile and Compressive Properties of Natural Hybrid Composites. 

